\title{
A Practical Application of X-Ray Spectroscopy in Ti-Al-N and Cr-Al-N Thin Films
}

\author{
Leonid Ipaz ${ }^{1}$, William Aperador2,3, Julio Caicedo ${ }^{1}$, \\ Joan Esteve ${ }^{4}$ and Gustavo Zambrano ${ }^{1}$ \\ ${ }^{1}$ Thin Films Group, Physics Department, University of Valle \\ ${ }^{2}$ Colombian School of Engineering Julio Garavito, Bogotá DC \\ ${ }^{3}$ Universidad Militar Nueva Granada, Bogota DC \\ ${ }^{4}$ Department of Applied Physics Optics, Universitat de Barcelona \\ 1,2,3 Colombia \\ ${ }^{4}$ Spain
}

\section{Introduction}

Binary and ternary transition metal nitrides coatings have been used in numerous applications to increase the hardness and improve the wear and corrosion resistance of structural materials, as well as in various high-tech areas, where their functional rather than tribological and mechanical properties are of prime importance (Münz, 1986; Chen \& Duh, 1991; PalDey \& Deevi, 2003; Ipaz et al., 2010). Up to now, Ti-Al-N and Cr-Al-N films have been synthesized by a variety of deposition techniques including cathodic arc evaporation (Cheng et al., 2001), ion plating (Setsuhara et al., 1997), chemical vapor deposition (CVD) or plasma-enhanced CVD (Shieh \& Hon, 2001) and d.c. / r.f. reactive magnetron sputtering (Musil \& Hruby, 2000; Sanchéz et al., 2010). Performance of these coatings is equally dependent on their chemical composition and long-range crystalline structure, as well as on the nature and amount of impurities and intergranular interactions. Significant improvement in the mechanical properties has recently been achieved with multicomponent superlattice, multilayers and nanocomposite nitride coatings. In the case of such multilayers systems, not only is close control of the elemental composition (stoichiometry) and modulation period necessary to optimize the properties of the coatings, but the influence of chemical bond formation between the components is also of prime importance. Therefore, it is necessary to take special care when the conditions of preparation are nonequilibrium, activation of CVD and PVD by plasmas or energetic particle beams are applied, occasionally leading to unpredicted deviations, both in composition and structure. As is highlighted in this study, nitride coatings or nitrided surfaces based in Chromium and Aluminium materials can be analyzed in detail by X-ray photoelectron spectroscopy (XPS) due to its excellent element selectivity, quantitative character and high surface sensitivity. More importantly, XPS reflects the atomic scale chemical interactions, i.e. the bonds between neighboring atoms $\mathrm{Cr}-\mathrm{N}, \mathrm{Al}-\mathrm{N}, \mathrm{Ti}-\mathrm{N}, \mathrm{Ti}-\mathrm{Al}-\mathrm{N}$ and thus it also provides reliable structural characteristics for amorphous or nano-crystalline coatings of complex composition, for which application of diffraction techniques is not straightforward. 


\section{Experimental details and results}

$[\mathrm{Ti}-\mathrm{Al} / \mathrm{Ti}-\mathrm{Al}-\mathrm{N}]_{\mathrm{n}}$ and $[\mathrm{Cr}-\mathrm{Al} / \mathrm{Cr}-\mathrm{Al}-\mathrm{N}]_{\mathrm{n}}$ multilayers films were deposited at a substrate temperature of $250{ }^{\circ} \mathrm{C}$ onto silicon (100) and AISI D3 steel substrates through magnetron co-sputtering pulsed dc method in (Ar/N2) gas mixture, from metallic binary target, 1:1 area ratio of $\mathrm{Ti}-\mathrm{Al}$ and $0.25: 0.75$ area ratio of $\mathrm{Cr}-\mathrm{Al}$, See fig 1 . The d.c. density power was $7.4 \mathrm{~W} / \mathrm{cm}^{2}$. The substrates were fixed to a holder $6.0 \mathrm{~cm}$ above the sputtering target. The deposition chamber was evacuated to a base pressure of $10^{-6}$ mbar before the introduction of the sputtering gas. Metallic single layer films (Ti-Al and $\mathrm{Cr}-\mathrm{Al}$ ) and metal nitride single layer films (Ti-Al-N and Cr-Al-N) were deposited by two different processes: the first one (Ti-Al and $\mathrm{Cr}-\mathrm{Al}$ materials), was carried out by using a pure Ar gas at $1.5 \times 10^{-3}$ mbar, the deposition time corresponding to the metallic layer ranged from 3 seconds and 300 seconds for $n=100$ and $n=1$, respectively (process A); the second one (TiAlN and Cr-Al$\mathrm{N}$ materials), was carried out by using a 50:50 and 90:10 $\mathrm{Ar}-\mathrm{N}_{2}$ ratio in gas mixture for TiAl-N and Cr-Al-N, respectively, at $1.5 \times 10^{-3}$ mbar, the deposition time corresponding to the nitride layer (Ti-Al-N) ranged from 15 seconds to 1500 seconds for $n=100$ and $n=1$, respectively (process $\mathrm{B}$ ). So, the multilayers were obtained by alternatively changing the deposition conditions from process A to process B until desired number of bilayers was deposited. To ensure good quality of the interface includes a stabilization period of 20 seconds between process A and B during this period were evacuated gases used in the above process.
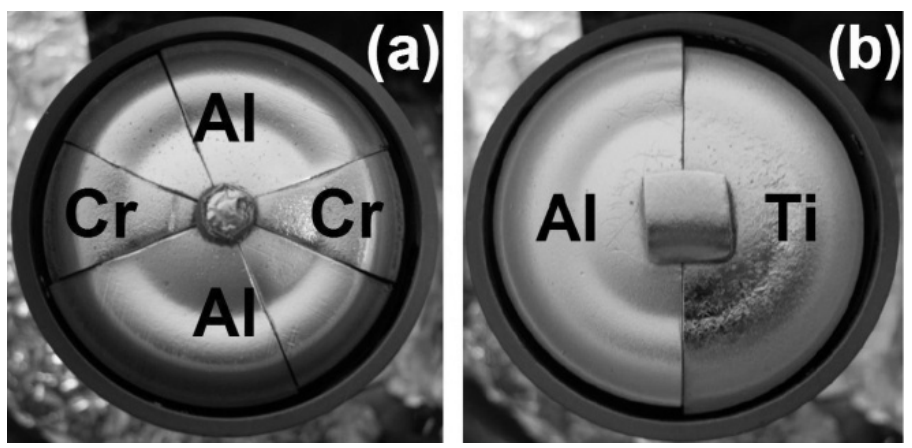

Fig. 1. Metallic binary targets (a) $\mathrm{Cr}-\mathrm{Al}$ target with 0.25:0.75 area ratio; (b) Ti-Al target with 1:1 area ratio.

The total multilayer thickness was approximately of $2.5 \mu \mathrm{m}$ for the multilayers deposited with different bilayer periods $(\Lambda)$ and of bilayers number $(\mathrm{n})$, which was varied between 2.5 $\mu \mathrm{m}$ and $25 \mathrm{~nm}$ and 1 and 100, respectively. The deposition parameters are showed in the Table 1. An exhaustive X-ray diffraction (XRD) study was carried out using a PANalytical $X^{\prime}$ Pert PRO diffractometer with $\mathrm{Cu}-\mathrm{Ka}$ radiation $(\alpha=1.5406 \AA)$ at Bragg-Brentano configuration $(\theta / 2 \theta)$ in high- and low-angle ranges.

The bilayer period and multilayer assembly modulation were observed via scanning electron microscopy (SEM) by using a Leika 360 Cambridge Instruments, equipped with a height sensitivity back-scattered electron detector. The total thickness and the ratio between thickness of Ti-Al and Ti-Al-N single layers was obtained by means of a (Dektak 3030) 
Profilometer. Additionally, a detailed X-ray photoelectron spectroscopy (XPS) study of TiAl-N coatings, was carried out, in order to determine the [Ti-Al/Ti-Al-N $]_{n}$ multilayer coatings chemical composition and the bonding of aluminum, titanium, and nitrogen atoms by using ESCAPHI 5500 monochromatic Al-Ka radiation and a passing energy of $0.1 \mathrm{eV}$, taking in account that surface sensitivity of this technique is so high and any contamination can produce deviations from the real chemical composition and, therefore, the XPS analysis is typically performed under vacuum conditions with some sputter cleaning source to remove any undesired contaminants.

Raman spectroscopy measurements were carried out on a micro Raman system (HR LabRam II by Jobin Yvon), using the $632.8 \mathrm{~nm}$ He-Ne laser line, attenuated 100 times with a 2 microns spot. For each Raman measurement the sample was exposed to the laser light for $5 \mathrm{~s}$ and 100 acquisitions were performed in order to improve the signal to noise ratio.

\begin{tabular}{|c|cc|}
\hline Process & A & B \\
& Metallic (Cr-Al; Ti-Al) layer & Nitride (Cr-Al-N; Ti-Al-N) layer \\
\hline Reactive gas sputtering & Pure $\mathrm{Ar}$ & $90 / 10 ; 50 / 50\left(\% \mathrm{Ar} / \% \mathrm{~N}_{2}\right)$ Mixture \\
Substrate temperature & $250^{\circ} \mathrm{C}$ & \\
Sputtering gas pressure & $1.5 \times 10^{-3} \mathrm{mbar}$ & \\
d.c. power & $7.4 \mathrm{~W} / \mathrm{cm}^{2}$ \\
Target & $(\mathrm{Cr}-\mathrm{Al} ; \mathrm{Ti}-\mathrm{Al})$ Binary \\
Substrate & Silicon $(100)$ \\
Target-substrate distance & $6 \mathrm{~cm}$ \\
\hline
\end{tabular}

Table 1. Process parameters for deposition of the $[\mathrm{Ti}-\mathrm{Al} / \mathrm{Ti}-\mathrm{Al}-\mathrm{N}]_{\mathrm{n}}$ and $[\mathrm{Cr}-\mathrm{Al} / \mathrm{Cr}-\mathrm{Al}-\mathrm{N}]_{\mathrm{n}}$ multilayers.

\subsection{Multilayer modulation analyzed by scanning electron microscopy}

A first glimpse on $[\mathrm{Ti}-\mathrm{Al} / \mathrm{Ti}-\mathrm{Al}-\mathrm{N}]_{\mathrm{n}}$ and $[\mathrm{Cr}-\mathrm{Al} / \mathrm{Cr}-\mathrm{Al}-\mathrm{N}]_{\mathrm{n}}$ multilayers modulation and microstructure was accomplished by SEM micrographs. Fig. 2a presents the cross-sectional image of a $[\mathrm{Ti}-\mathrm{Al} / \mathrm{Ti}-\mathrm{Al}-\mathrm{N}]_{\mathrm{n}}$ coating with bilayer number $(\mathrm{n}=10)$ and bilayer period $(\Lambda=250 \mathrm{~nm})$. The darkest contrast of Ti-Al-N layers with respect to Ti-Al layers allowed a clear determination of the layer structure. These $[\mathrm{Ti}-\mathrm{Al} / \mathrm{Ti}-\mathrm{Al}-\mathrm{N}]_{10}$ coatings presented a buffer layer of Ti-Al with thickness around $300 \mathrm{~nm}$, the Ti-Al/Ti-Al-N multilayer with total thickness around $2.5 \mu \mathrm{m}$ with well-defined and uniform periodicity. All the multilayer stacks were resolved by SEM and confirmed quite precisely the previously designed values of bilayer thickness, as well as the total thicknesses. The only slight deviation observed by SEM imaging was on relative thicknesses. Fig. $2 \mathrm{~b}$ presents the cross-sectional image of a [Cr$\mathrm{Al} / \mathrm{Cr}-\mathrm{Al}-\mathrm{N}]_{\mathrm{n}}$ multilayer films with $\mathrm{n}=10(\Lambda=200 \mathrm{~nm})$. The darkest contrast of $\mathrm{Cr}-\mathrm{Al}-\mathrm{N}$ layers with respect to $\mathrm{Cr}-\mathrm{Al}$ layers allowed a clear determination of the layer structure. These $[\mathrm{Cr}-\mathrm{Al} / \mathrm{Cr}-\mathrm{Al}-\mathrm{N}]_{10}$ films presented a buffer layer of $\mathrm{Cr}-\mathrm{Al}$ with thickness around $300 \mathrm{~nm}$, the Ti-Al/Ti-Al-N multilayer with thickness around $2.0 \mu \mathrm{m}$ with well-defined and uniform periodicity. 

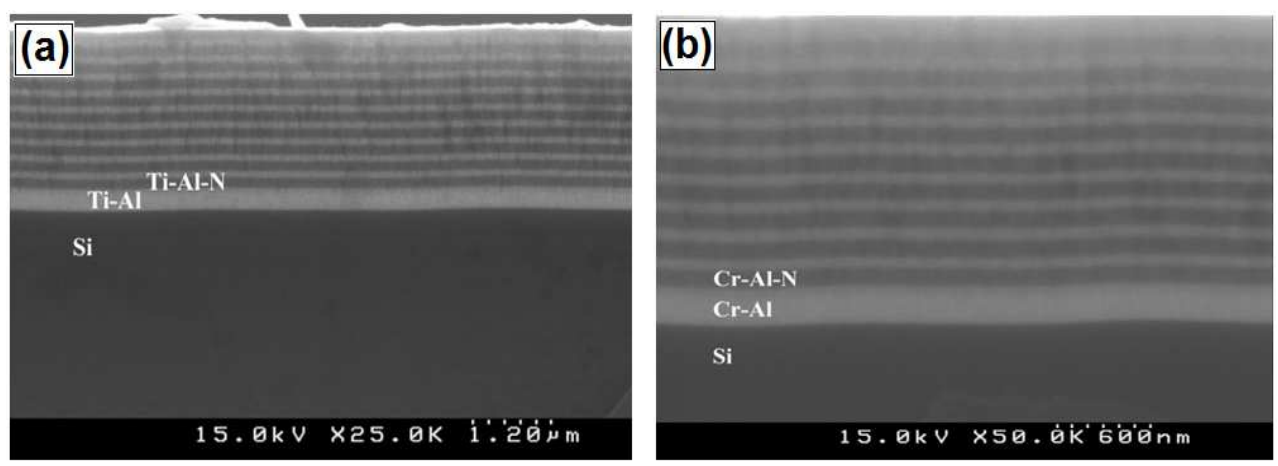

Fig. 2. SEM micrograph of (a) $[\mathrm{Ti}-\mathrm{Al} / \mathrm{Ti}-\mathrm{Al}-\mathrm{N}]_{10}$ with $\mathrm{n}=10, \Lambda=200 \mathrm{~nm}$ and (b) $[\mathrm{Cr}-\mathrm{Al} / \mathrm{Cr}-$ Al-N] $]_{10}$ films with $\mathrm{n}=10, \Lambda=300 \mathrm{~nm}$.

\subsection{X-ray analyses of [Ti-Al/Ti-Al-N $]_{\mathrm{n}}$ and $[\mathrm{Cr}-\mathrm{Al} / \mathrm{Cr}-\mathrm{Al}-\mathrm{N}]_{\mathrm{n}}$ multilayer coatings}

\subsection{1 [Ti-Al/Ti-Al-N]n multilayer}

Fig. 3 shows a typical XRD diffraction patterns of $[\mathrm{Ti}-\mathrm{Al} / \mathrm{Ti}-\mathrm{Al}-\mathrm{N}]_{\mathrm{n}}$ multilayers deposited onto Si (100) substrate with a period of $\Lambda=42 \mathrm{~nm}(\mathrm{n}=60)$, and $\Lambda=25 \mathrm{~nm}(\mathrm{n}=100)$. Diffraction patterns show that the $[\mathrm{Ti}-\mathrm{Al} / \mathrm{Ti}-\mathrm{Al}-\mathrm{N}]_{\mathrm{n}}$ multilayer systems exhibit a polycrystalline structure with a (200) preferential orientation corresponding to TiAlN phase located at $43.72^{\circ}$. Other peaks present in the diffraction patterns can be seen in Table 2 . (Schönjahn et al., 2000; Qu et al., 2002)
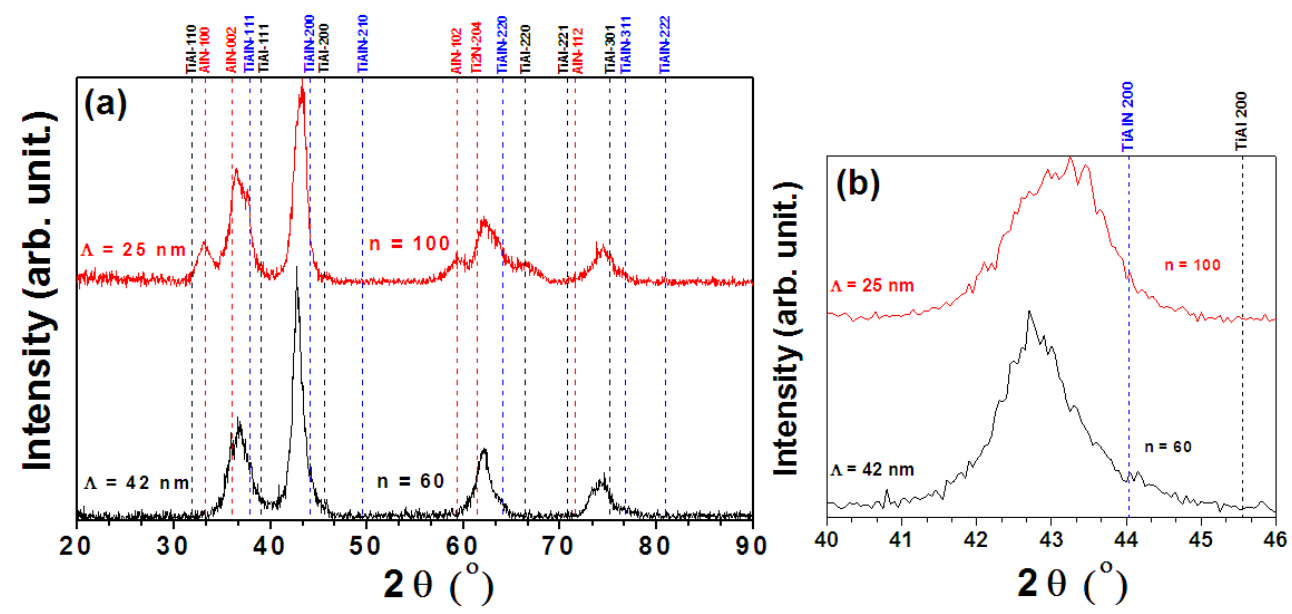

Fig. 3. XRD patterns of the $[\mathrm{Ti}-\mathrm{Al} / \mathrm{Ti}-\mathrm{Al}-\mathrm{N}]_{\mathrm{n}}$ multilayer coatings deposited on $\mathrm{Si}(100)$ substrates with a period of $\Lambda=42 \mathrm{~nm}(\mathrm{n}=60)$ and $\Lambda=25 \mathrm{~nm}(\mathrm{n}=100)$. Dash lines indicate the position of the peaks obtained from JCPDF 00-037-1140 (TiAlN), JCPDF 00-005-0678 (TiAl) and JCPDF 00-003-1144 (AIN) files from ICCD cards and (b) maximum peak shifts toward higher angles in relationship to increasing bilayer number (n). 


\begin{tabular}{|c|c|c|c|c|c|c|c|}
\hline Phase & $\begin{array}{c}\text { Ti-Al-N } \\
\text { Cubic }\end{array}$ & \multicolumn{3}{|c|}{$\begin{array}{c}\text { AlN } \\
\text { Hexagonal }\end{array}$} & \multicolumn{2}{c|}{$\begin{array}{c}\text { TiAl } \\
\text { Tetragonal }\end{array}$} & $\begin{array}{c}\text { Ti2N } \\
\text { Hexagonal }\end{array}$ \\
\hline Plane (hkl) & $\begin{array}{c}(200) \\
(111)\end{array}$ & $(100)$ & $(002)$ & $(102)$ & $\begin{array}{l}(200) \\
(220)\end{array}$ & $(301)$ & $(204)$ \\
\hline $\begin{array}{c}\text { Diffraction angle } \\
\left(^{\circ}\right)\end{array}$ & $\begin{array}{c}43.72 \\
\text { (36.61 }\end{array}$ & 33.00 & 36.28 & 59.56 & $\begin{array}{l}45.55 \\
66.44\end{array}$ & 74.38 & 83.24 \\
\hline
\end{tabular}

Table 2. Peaks present in diffraction patterns.

These preferential orientations are in agreement with JCPDF 00-037-1140 (TiAlN) JCPDF 00-005-0678 (TiAl) and JCPDF 00-003-1144 (AlN) from ICCD cards. The shift of the diffraction patterns toward high angles is in relation to the compressive residual stress characteristics for those multilayer systems deposited by magnetron sputtering technique. Therefore, it was observed that the Ti-Al-N (200) peak position suffers a great deviation from the bulk value indicating a possible stress evolution of Ti-Al/Ti-Al-N layers with the bilayer period (see Fig. 3b). The quasi-relaxed position observed for thinner bilayer periods was progressively shifted to higher compressive stress values when the bilayer period is reduced until the $\Lambda=25 \mathrm{~nm}$, therefore, this compressive effect is reached due to the multilayer mechanism is actuated on Ti-Al/Ti-Al-N coatings. For thinner period multilayers ( $\mathrm{n}=100)$, an abrupt change in Ti Al N (220) peak position was observed, presenting a stress relieving due to the movement of this peak toward higher angles compared to other multilayer, but close to bulk value $\left(44.04^{\circ}\right)$. The stress evolution in $\mathrm{Ti}$ Al-N (200) peak position comes together with a progressive and intense symmetric broadening and a increasing in its intensity. Moreover, in these patterns is shown clearly not presences of satellite peaks with the increasing in the bilayers number and the thickness reduction of individual layers, which indicate low structural coherency in relation to the lowest bilayer period $(\Lambda=25 \mathrm{~nm})$ (Tien \& Duh., 2006).

\subsection{2 [Cr-Al/Cr-Al-N] multilayer}

In $\mathrm{Cr}-\mathrm{Al} / \mathrm{Cr}-\mathrm{Al}-\mathrm{N}$ multilayer, the individual thickness was varied in function of bilayer number from $n=1$ to $n=100$, producing bilayer period $(\Lambda)$ from $2000 \mathrm{~nm}$ to $20 \mathrm{~nm}$. So, the Fig. 4a shows the XRD pattern of $\mathrm{Cr}-\mathrm{Al} / \mathrm{Cr}-\mathrm{Al}-\mathrm{N}$ coatings deposited with $\mathrm{n}=60, \Lambda=33 \mathrm{~nm}$; and $n=100, \Lambda=20 \mathrm{~nm}$ onto $\mathrm{Si}(100)$ substrate; the XRD pattern presents a cubic structure were the strongest peak corresponds to $\mathrm{CrN}$ (200) plane, indicating a light textured growth along this orientation.

The weak peaks correspond to diffractions of $\mathrm{CrN}$ (111), $\mathrm{CrN}$ (220), $\mathrm{CrN}$ (103), CrAl (514), CrAl (550), AlN (110) and (222) planes of the FCC structure. Moreover, the AlN (422), peak for the AlN within Cr-Al-N material are exhibited. On the other hand, it was observed that the $\mathrm{CrN}$ (200) peak position suffers a great deviation from bulk value indicating a possible stress evolution of $\mathrm{Cr}-\mathrm{Al} / \mathrm{Cr}-\mathrm{Al}-\mathrm{N}$ layers with the bilayer period (Fig. 4b). The quasi-relaxed position observed for thinner bilayer periods was progressively shifted to higher compressive stress values as the bilayer period is reduced until the $\Lambda=20 \mathrm{~nm}$, therefore, this compressive effect is reached due to multilayer 
mechanism actuating on $\mathrm{Cr}-\mathrm{Al} / \mathrm{Cr}-\mathrm{Al}-\mathrm{N}$ coatings. For thinner period multilayers $(\mathrm{n}=100)$, an abrupt change in $\mathrm{CrN}$ (200) peak position was observed, presenting a stress relieving due to the movement of this peak towards higher angles compared to other multilayer but close to bulk value $\left(43.71^{\circ}\right)$. The stress evolution in $\mathrm{CrN}$ (200) peak position comes together with a progressive and intense symmetric broadening and a increasing in its intensity. Moreover in these patterns is shown clearly not presences of satellite peaks with the increasing in the bilayers number and the thickness reduction of individual layers, which indicate low structural coherency in relation to the lowest bilayer period $(\Lambda=20$ nm) (Yashar \& Sproul, 1999).
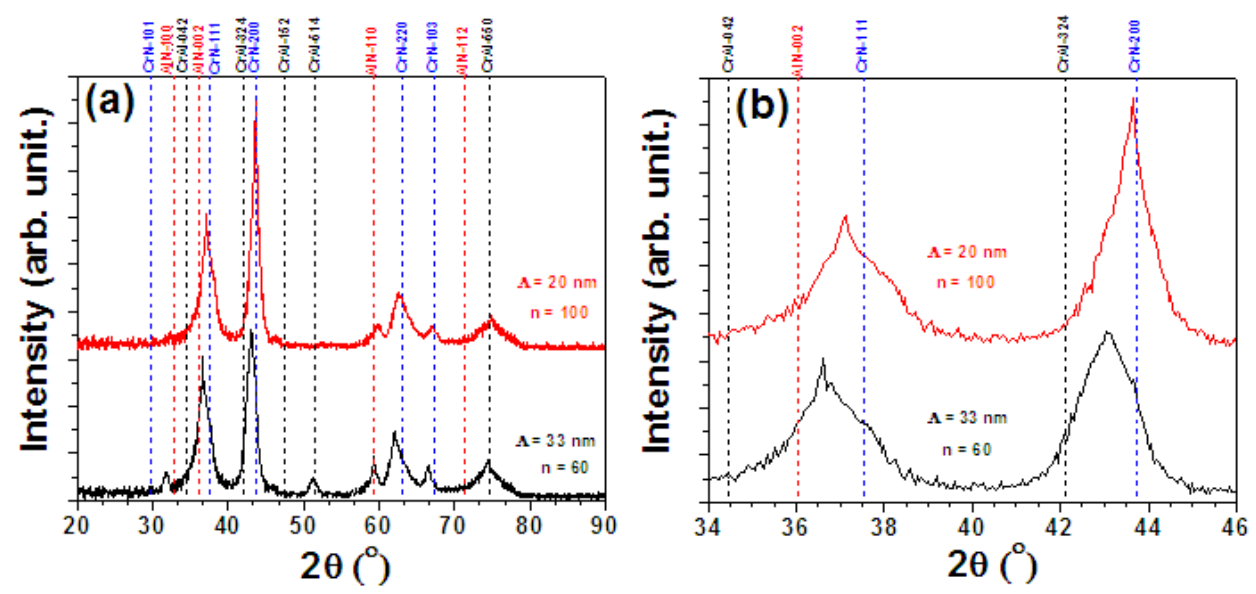

Fig. 4. XRD patterns of the $[\mathrm{Cr}-\mathrm{Al} / \mathrm{Cr}-\mathrm{Al}-\mathrm{N}]_{\mathrm{n}}$ multilayer coatings deposited on $\mathrm{Si}(100)$ substrates with a period of $\Lambda=33 \mathrm{~nm}(\mathrm{n}=60)$ and $\Lambda=20 \mathrm{~nm}(\mathrm{n}=100)$. (a) Dash lines indicate the position of the peaks obtained from JCPDF 00-001-1232 (CrN), JCPDF 00-0021192 (CrAl) and JCPDF 00-003-1144 (AlN) files from ICCD cards and (b) maximum peak shifts toward higher angles in relationship to increasing bilayer number (n).

\subsection{Compositional nature analyzed by X-ray photoelectron spectroscopy (XPS)}

An exhaustive X-ray photoelectron spectroscopy (XPS) study was carried out for $\mathrm{Ti}-\mathrm{Al} / \mathrm{Ti}-\mathrm{Al}-\mathrm{N}$ and $\mathrm{Cr}-\mathrm{Al} / \mathrm{Cr}-\mathrm{Al}-\mathrm{N}$ multilayer films. XPS was used on [Ti-Al/Ti-Al-N $]_{\mathrm{n}}$ and $[\mathrm{Cr}-\mathrm{Al} / \mathrm{Cr}-\mathrm{Al}-\mathrm{N}]_{\mathrm{n}}$ samples to determine the chemical composition and the bonding of titanium, aluminium, chromium and nitrogen atoms using ESCAPHI 5500 monochromatic $\mathrm{Al} \mathrm{Ka}$ radiation and a passing energy of $0.1 \mathrm{eV}$. The surface sensitivity of this technique is so high that any contamination can produce deviations from the real chemical composition and, therefore, the XPS analysis is typically performed under ultra high vacuum conditions with a sputter cleaning source to remove any undesired contaminants. 
The XPS survey spectrum for TiAl/TiAlN films is shown in Fig. 5. The peaks at $532.8 \mathrm{eV}$, $457.6 \mathrm{eV}, 463.5 \mathrm{eV}, 397 \mathrm{eV}$ and $73.9 \mathrm{eV}$ correspond to O1s, Ti2p, Ti2p1/2, N1s and Al2p3/2 binding energies, respectively. Calculation of the peak areas without $\mathrm{Ti}, \mathrm{Al}$ and $\mathrm{N}$ contribution gives an atomic ratio of Ti:Al: $\mathrm{N}=2.077: 0.256: 0.499$.

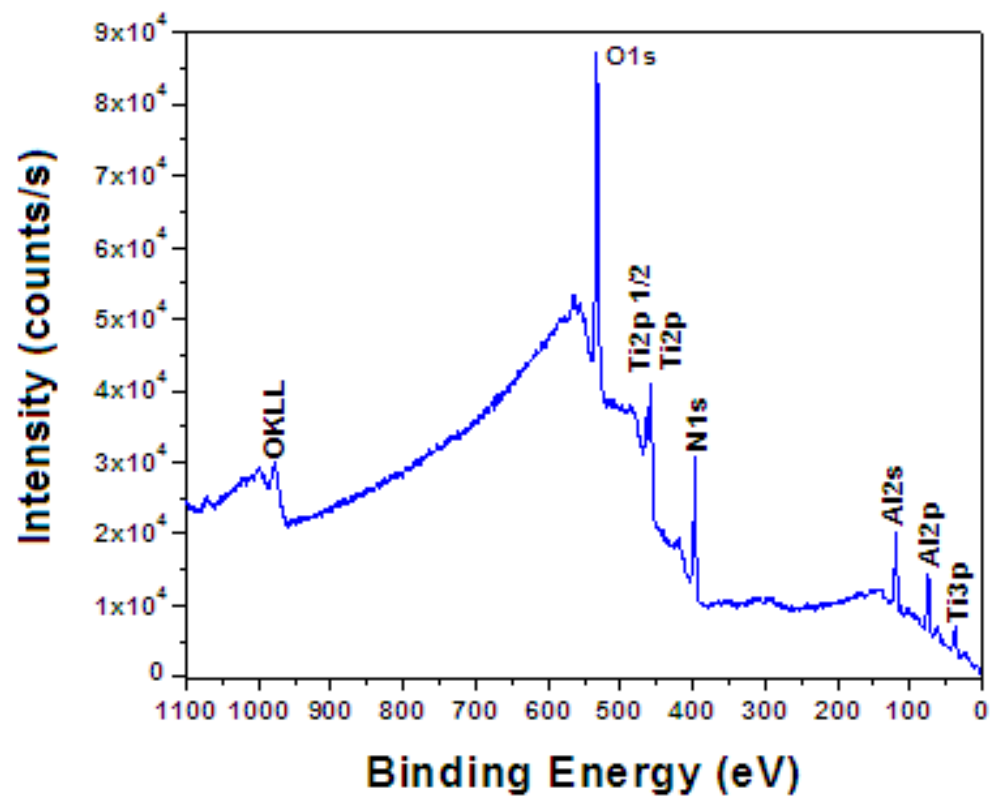

Fig. 5. XPS survey spectrum of Ti-Al-N coatings deposited on Si (100).

According to the XPS literature around Ti-Al-N materials (Fox-Rabinovich et al., 2008; Shum et al., 2003), when the peaks are fitted from experimental results, it is necessary to adjust first the $\mathrm{N}$ energy band because it is the element that provides greater reliability for XPS, then, take this first adjust as base, the other peaks related to the remaining elements are adjusted. The latter is indispensable due to the characteristic that is present in this kind of insulating materials (coatings) with respect to the incident signal, avoiding in this way the uncertainties caused for charging and shifts of the Fermi energy. Thus, the concentration measurements and the identification of the specific bonding configurations for the Ti-Al-N layer are more reliable. So, the core electronic spectra carry the information of the chemical composition and bonding characters of the Ti-Al-N films. The integral of O1s, Ti2p, $\mathrm{Al} 2 \mathrm{p} 3 / 2$, and N1s spectra corrected by relevant sensitive factors can evaluate the concentrations of $\mathrm{Ti}, \mathrm{Al}$, and $\mathrm{N}$ elements in the Ti-Al-N films. The corresponding integral of the deconvoluted peaks can also be used to estimate the bond contents, which are described by the following equation (Moreno et al., 2011): 


$$
C_{i}=\sum\left(A_{i} / S_{i}\right) /\left(A_{j} / S_{j}\right)
$$

Where $\mathrm{S}$ is the sensitivity factor, $\mathrm{A}$ is the integral of deconvoluted peaks, and $\mathrm{C}$ is the atomic content. The numerator is the sum of the integral of one sort of bond; the denominator is the sum of the integral of all types of bonds decomposed from the whole peak of O1s, Ti2p, $\mathrm{Al} 2 \mathrm{p} 3 / 2$, and N1s spectra in the sample. The atomic concentrations of $\mathrm{Ti}, \mathrm{Al}, \mathrm{N}$, and $\mathrm{O}$ elements from XPS analysis of the coating with $\mathrm{n}=1$ and $\Lambda=2.5 \mu \mathrm{m}$ are listed in Table 3, where is observed that Ti-Al-N materials is an over- stoichiometric compound. For the all obtained Ti-Al-N films, the $\mathrm{O}$ concentration is less than that 3 at. \%. Moreover when the substrate is heated to $250{ }^{\circ} \mathrm{C}$ during the deposition process, the atomic compositions in the films almost remain unchanged.

\begin{tabular}{|c|c|c|c|}
\hline \multicolumn{2}{|c|}{ Atomic composition (at.\%) } & \multirow{2}{*}{ (Ti+Al/N) } \\
\cline { 1 - 2 } Ti & Al & N & \multirow{2}{*}{1.45} \\
\cline { 1 - 2 } 19.83 & 39.34 & 40.83 & \\
\hline
\end{tabular}

Table 3. Atomic composition of $[\mathrm{Ti}-\mathrm{Al} / \mathrm{Ti}-\mathrm{Al}-\mathrm{N}]_{\mathrm{n}}$ coating with $\mathrm{n}=1$ and $\Lambda=2.5 \mu \mathrm{m}$

The high-resolution spectra of Ti2p, N1s and Al2p3/2 were recorded from TiAlN coatings, as shown in Fig. 6. From Fig. 6(a), the Ti2p peak is composed of spin doublets, each separated by $6.1 \mathrm{eV}$. The XPS spectrum of Ti2p can be fitted well by two Gaussian functions. The values of binding energies obtained for the Ti2p1/2 peak were $463.7 \mathrm{eV}$ and the lower value for Ti2p was $457.6 \mathrm{eV}$.

According to the literature (Tam et al., 2008; Kim et al., 2002) for the Ti2p1/2 peak, the first one $(463.5 \mathrm{eV})$ and the second one $(458.6 \mathrm{eV})$ can be assigned to Ti-O2 and Ti-N bonds. The appearance of the peak at $457.6 \mathrm{eV}$ clearly shows that Ti has reacted with $\mathrm{N}$; therefore, it can be assigned to Ti-N (Badrinarayanan et al., 1989; Moreno et al. 2011).

Fig. 6(b) depicts the N1s spectrum. The N1s peak can be deconvoluted in four peaks at $396.9 \mathrm{eV}, 398.0 \mathrm{eV}$, and $400 \mathrm{eV}$ characteristic for Ti-N $\mathrm{N}_{X}, \mathrm{Ti}-\mathrm{N}$ and N-O, respectively (Shum et al., 2003; Shulga et al., 1976; Hironobu et al., 2003). Fig. 3(c) shows the Al2p3/2 spectrum. Four fitting peaks of the $\mathrm{Al}$ peak can be deconvoluted at $72.8 \mathrm{eV}, 73.9 \mathrm{eV}, 75.5 \mathrm{eV}$ and 77.3 $\mathrm{eV}$, moreover these peaks are associated to the $\mathrm{Al}-\mathrm{Al}$ bond, $\mathrm{Al}-\mathrm{N}, \mathrm{Al}_{\mathrm{x}} \mathrm{O}$ and $\mathrm{Al}_{2}-\mathrm{O}_{3}$ with a single bond, respectively (Shum et al., 2003; Taylor \& Rabalais, 1981; Lindsay et al., 1973). The XPS results demonstrate that $\mathrm{Ti}$ and the $\mathrm{Al}$ atoms have been bonded with $\mathrm{N}$ in the forms of nitride the elemental concentration of the Ti-Al-N film was controlled by adjusting the applied power of the Ti-Al binary target, and the $\mathrm{Ar} / \mathrm{N}_{2}$ gas mixture. Generally, formative $\mathrm{N}(\mathrm{Ti}, \mathrm{Al})$ phase with good crystallization indicates that the aluminium and titanium activity and activation energy provided by the present deposition conditions are enough for the formation of a Ti-Al-N film. Although the surface temperature of the substrate during deposition of a Ti-Al-N film is around $250{ }^{\circ} \mathrm{C}$, the substrate lies in a highdensity plasma region and a high ion-to-atom ratio of titanium, aluminium and nitrogen can be propitious to the formation of $\mathrm{Ti}-\mathrm{Al}-\mathrm{N}$ phase proven by XPS results. 


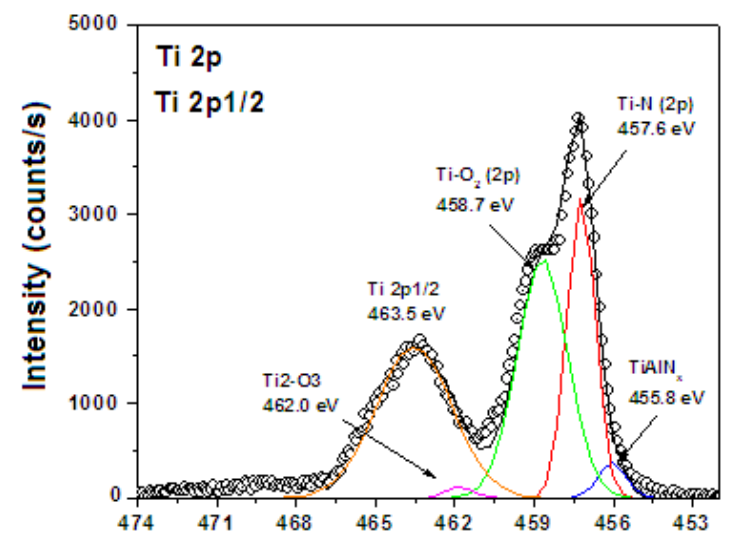

(a) Binding energy (eV)

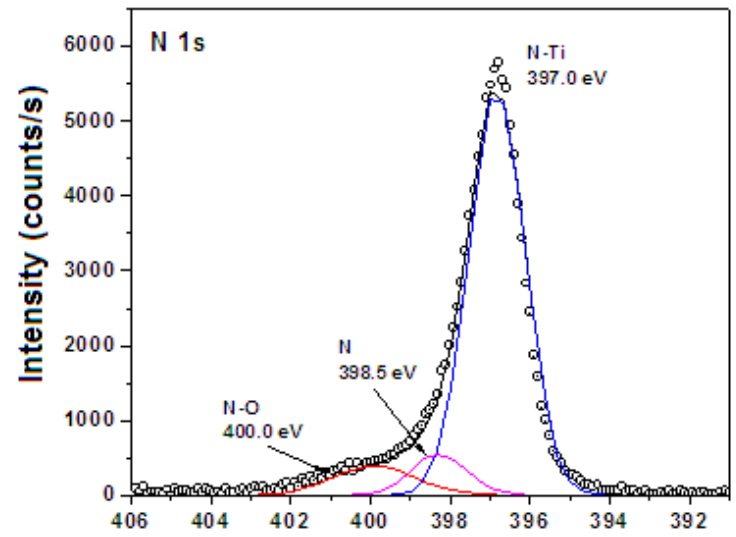

(b)

Binding Energy $(\mathrm{eV})$

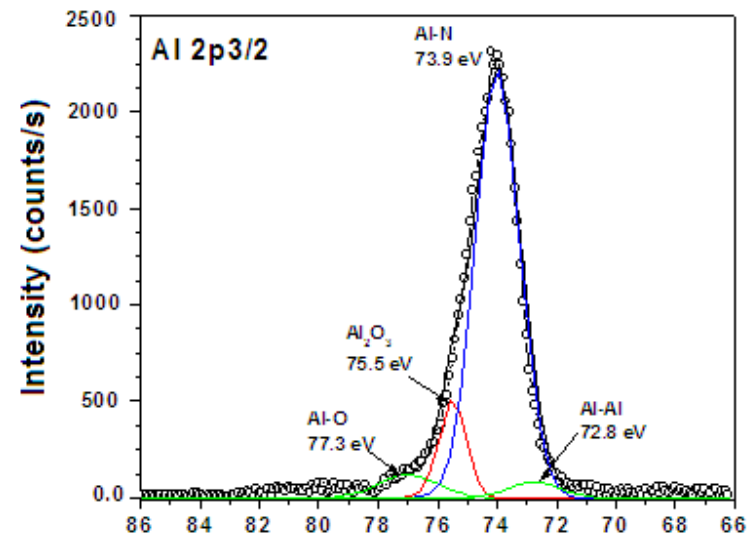

(c)

Binding energy $(\mathrm{eV})$

Fig. 6. High-resolution spectrum of (a) Ti2p, (b) N1s and (c) Al2p3/2 from Ti-Al/Ti-Al-N film. 
On the other hand, the XPS survey spectrum for Cr-Al/Cr-Al-N films is shown in Fig. 7. The peaks at $532.8 \mathrm{eV}, 397 \mathrm{eV}, 73.9 \mathrm{eV}$, and $575.6 \mathrm{eV}$ correspond to $\mathrm{O} 1 \mathrm{~s}, \mathrm{~N} 1 \mathrm{~s}, \mathrm{Al} 2 \mathrm{p} 3 / 2$ and $\mathrm{Cr} 2 \mathrm{p} 3 / 2$ binding energies, respectively. Calculation of the peak areas without $\mathrm{Cr}, \mathrm{Al}$ and $\mathrm{N}$ contribution gives an atomic ratio of $\mathrm{Cr}: \mathrm{Al}: \mathrm{N}=0.341: 1.978: 0.398$.

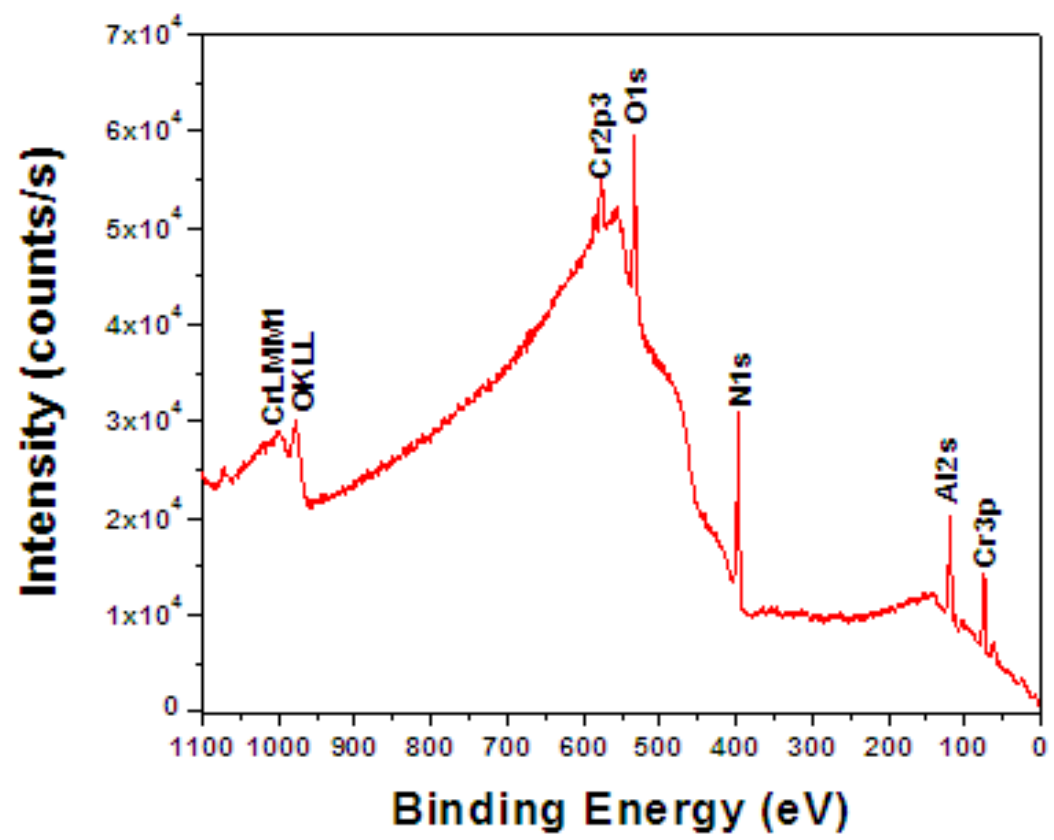

Fig. 7. XPS survey spectrum of Cr-Al-N coatings deposited on Si (100).

According to the XPS literature around Cr-Al-N materials (Barshilia et al., 2007; Del Re et al., 2003; Sanjinés et al., 2002), when the peaks are fitted from experimental results, it is necessary to adjust first the $\mathrm{N}$ energy band because it is the element that provides greater reliability for XPS, then, take this first adjust as base, the other peaks related to the remaining elements are adjusted. The latter is indispensable due to the characteristic that is present in this kind of insulating materials (films) with respect to the incident signal, avoiding in this way the uncertainties caused for charging and shifts of the Fermi energy. Thus, the concentration measurements and the identification of the specific bonding configurations for the $\mathrm{Cr}-\mathrm{Al}-\mathrm{N}$ layer are more reliable. So, the core electronic spectra carry the information of the chemical composition and bonding characters of the Cr-Al-N films. The integral of $\mathrm{O} 1 \mathrm{~s}, \mathrm{~N} 1 \mathrm{~s}, \mathrm{Al} 2 \mathrm{p} 3 / 2$, and $\mathrm{Cr} 2 \mathrm{p} 3 / 2$ spectra corrected by relevant sensitive factors can evaluate the concentrations of $\mathrm{Cr}, \mathrm{Al}$, and $\mathrm{N}$ elements in the $\mathrm{Cr}-\mathrm{Al}-\mathrm{N}$ films. The corresponding integral of the deconvoluted peaks can also be used to estimate the bond contents, which are described by the following equation (Moreno et al., 2011): 


$$
C_{i}=\sum\left(A_{i} / S_{i}\right) / \sum\left(A_{j} / S_{j}\right)
$$

where $\mathrm{S}$ is the sensitivity factor, $\mathrm{A}$ is the integral of deconvoluted peaks, and $\mathrm{C}$ is the atomic content. The numerator is the sum of the integral of one sort of bond; the denominator is the sum of the integral of all types of bonds decomposed from the whole peak of O1s, N1s, $\mathrm{Al} 2 \mathrm{p} 3 / 2$ and $\mathrm{Cr} 2 \mathrm{p} 3 / 2$ spectra in the sample. The atomic concentrations of $\mathrm{Cr}, \mathrm{Al}, \mathrm{N}$, and $\mathrm{O}$ elements from XPS analysis of the coating with $n=1$ and $\Lambda=2 \mu \mathrm{m}$ are listed in Table 4 . For all the $\mathrm{Cr}-\mathrm{Al}-\mathrm{N}$ films obtained, the $\mathrm{O}$ concentration is less than 3 at.\%. Moreover when the substrate is heated to $250{ }^{\circ} \mathrm{C}$, the atomic compositions in the films almost remain unchanged.

\begin{tabular}{|c|c|c|c|}
\hline \multicolumn{2}{|c|}{ Atomic composition (at.\%) } & \multirow{2}{*}{$(\mathbf{C r}+\mathrm{Al} / \mathbf{N})$} \\
\hline $\mathbf{C r}$ & $\mathbf{A l}$ & $\mathbf{N}$ & \multirow{2}{*}{2.09} \\
\cline { 2 - 3 } 38.27 & 29.71 & 32.46 & \\
\hline
\end{tabular}

Table 4. Atomic composition of $[\mathrm{Cr}-\mathrm{Al} / \mathrm{Cr}-\mathrm{Al}-\mathrm{N}]_{\mathrm{n}}$ coating with $\mathrm{n}=1$ and $\Lambda=2.0 \mu \mathrm{m}$

The high-resolution spectra of $\mathrm{Cr} 2 \mathrm{p}, \mathrm{N} 1 \mathrm{~s}$ and $\mathrm{Al} 2 \mathrm{p}$ were recorded from CrAlN coatings, as shown in Fig. 8. From Fig. 8a, the Cr2p peak is composed of spin doublets, each separated by $9.9 \mathrm{eV}$. The XPS spectrum of Cr2p can be fitted well by two Gaussian functions. The values of binding energies obtained for the $\mathrm{Cr} 2 \mathrm{p} 3 / 2$ peak were $575.6 \mathrm{eV}, 578.3 \mathrm{eV}$ associated at $\mathrm{Cr}-\mathrm{N}$ bonds and the lower value for $\mathrm{Cr} 2 \mathrm{p} 1 / 2$ was $585.5 \mathrm{eV}$.

According to the literature (Barshilia et al., 2007; Allen \& Tucker, 1976; Geoffrey et al., 1973) for the Cr2p peak, the first composed of two peaks ( $575.6 \mathrm{eV}$ and $578.3 \mathrm{eV}$ ) associated to $\mathrm{Cr}-$ $\mathrm{N}$ and $\mathrm{Cr}-\mathrm{O} 3$ bonds and the second one $(585.5 \mathrm{eV})$ can be assigned to $\mathrm{Cr}-\mathrm{N}$ bond. The appearance of the peaks at $575.6 \mathrm{eV}$ and $585.5 \mathrm{eV}$ clearly shows that $\mathrm{Cr}$ has reacted with $\mathrm{N}$.

Fig. $8 \mathrm{~b}$ depicts the N1s spectrum. The N1s peak can be deconvoluted in two peaks at 396.4 $\mathrm{eV}$ and $397.2 \mathrm{eV}$ characteristic for $\mathrm{Cr}-\mathrm{N}$ and $\mathrm{Cr}_{2}-\mathrm{N}$, respectively (Del Re et al., 2003; Nishimura et al., 1989).

Fig. 5(c) shows the Al2p3/2 spectrum. Four fitting peaks of the Al peak can be deconvoluted in four peaks at $72.8 \mathrm{eV}, 73.9 \mathrm{eV}, 75.5 \mathrm{eV}$ and $77.3 \mathrm{eV}$, moreover these peaks are associated to the $\mathrm{Al}-\mathrm{Al}$ bond, $\mathrm{Al}-\mathrm{N}, \mathrm{Al}_{\mathrm{x}}-\mathrm{O}$ and $\mathrm{Al}_{2} \mathrm{O}_{3}$ with a single bond, respectively (Lindsay et al., 1973; Sanjinés et al., 2002; Briggs \& Seah, 1994; Taylor, 1982; Kuo \& Tsai, 2000; Barr, 1983; Endrino et al., 2007). The XPS results demonstrate that $\mathrm{Cr}$ and the $\mathrm{Al}$ atoms have been bonded with $\mathrm{N}$ in the forms of nitride. The elemental concentration of the $\mathrm{Cr}-\mathrm{Al}-\mathrm{N}$ film was controlled by adjusting the applied power of the $\mathrm{Cr}-\mathrm{Al}$ binary target, and the $\mathrm{Ar} / \mathrm{N}_{2}$ gas mixture. Generally, formative $\mathrm{N}(\mathrm{Cr}, \mathrm{Al})$ phase with good crystallization indicates that the aluminium and titanium activity and activation energy provided by the present deposition conditions are enough for the formation of a $\mathrm{Cr}-\mathrm{Al}-\mathrm{N}$ coating. Although the surface temperature of the substrate during deposition of a Cr-Al$\mathrm{N}$ film is around $250{ }^{\circ} \mathrm{C}$, the substrate lies in a high-density plasma region and a high ionto-atom ratio of chromium, aluminium and nitrogen can be propitious to the formation of $\mathrm{Cr}-\mathrm{Al}-\mathrm{N}$ phase proven by XPS results. 


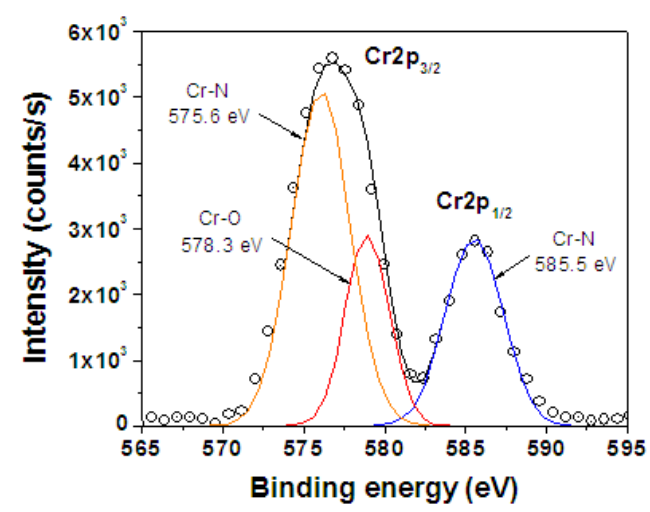

(a)

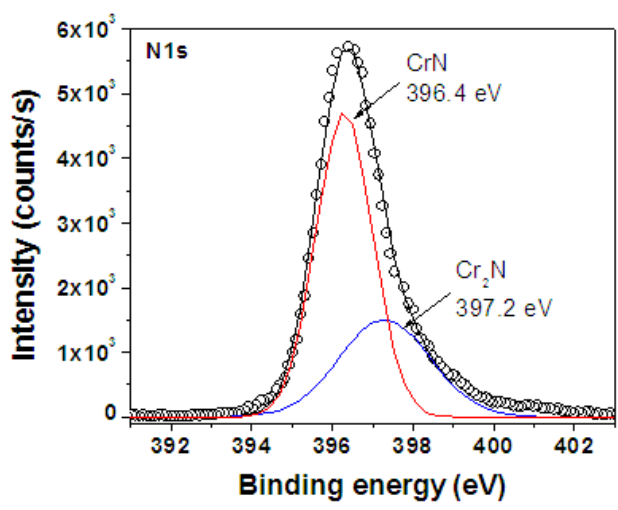

(b)

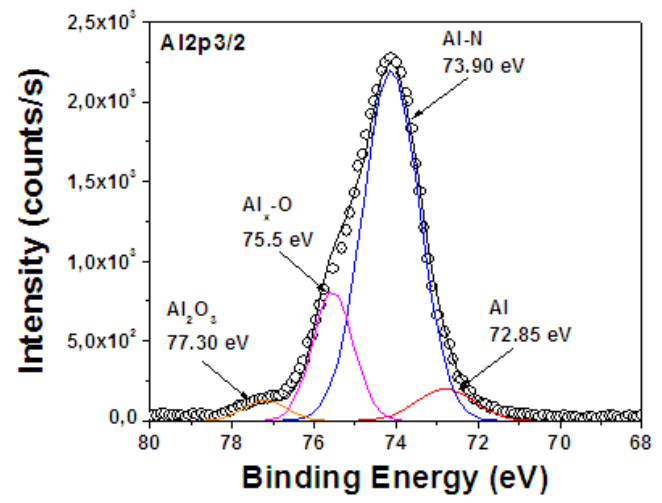

(c)

Fig. 8. High-resolution spectrum of (a) Cr2p, (b) N1s and (c) Al2p3/2 from Cr-Al/Cr-Al-N film

\subsection{Raman spectroscopy analysis of Ti-Al-N and Cr-Al-N films}

Raman spectroscopy has been widely used to analyze the present phases in thin films, in this work we used this technique to study ternary nitrides based in transition metals $(\mathrm{Cr}, \mathrm{Al}$ and Ti). From structural nature of Ti-Al-N and Cr-Al-N, it is known that addition of $\mathrm{Al}$ to $\mathrm{TiN}$ films or $\mathrm{Al}$ to $\mathrm{CrN}$ films changes the structure of the dominating phases from the facecentered cubic $(f c c)$ to the hexagonal wurtzite. In a perfect crystal with fcc structure, every ion is at a site of inversion symmetry, In consequence, vibration-induced changes in the electronic polarizability, necessary for Raman-scattering, are zero no first-order Raman effect can be observed. When the inversion symmetry is destroyed at the neighboring sites, certain atomic displacements have non-zero first-order polarizability derivatives and Raman scattering is induced. In the case of metal-nitride coatings, lattice defects, interstitial phases and "impurities" of the diatomic cubic coating structure render certain atomic displacements Raman active. Simple factor group analysis shows that both optic and 
acoustic branches give rise to Raman bands according to $\Gamma=A_{1 g}+E_{g}+T_{2 g}$ in the $O_{h}$ impuritysite symmetry (Montgomery et al., 1972; Constable et al., 1999).

\subsubsection{Ti-Al-N films}

In the Figure 9. shows Raman spectra of Ti-Al-N films in the range of 0 to $1500 \mathrm{~cm}^{-1}$. Raman spectra can be fitted well with five Gaussian-Lorentzian peaks at approximately 210, 320, 476 and $620 \mathrm{~cm}^{-1}$. The spectrum of Ti-Al-N showed two broad bands centered at 210 and 620 $\mathrm{cm}^{-1}$. These bands originate due to the first-order transverse acoustic in the $150-350 \mathrm{~cm}^{-1}$ region (LA and TA) and the optic modes in the $400-650 \mathrm{~cm}^{-1}$ region (LO and TO). Additionally was observed at $476 \mathrm{~cm}^{-1}$ the second-order acoustic (2A), at $735 \mathrm{~cm}^{-1}$ the transverse optical (TO) mode (Constable et al., 1999; Shum et al., 2004).

Higher frequency spectral density then arises via second-order transitions $(A+O)$ in the range of 700 to $900 \mathrm{~cm}^{-1}$.

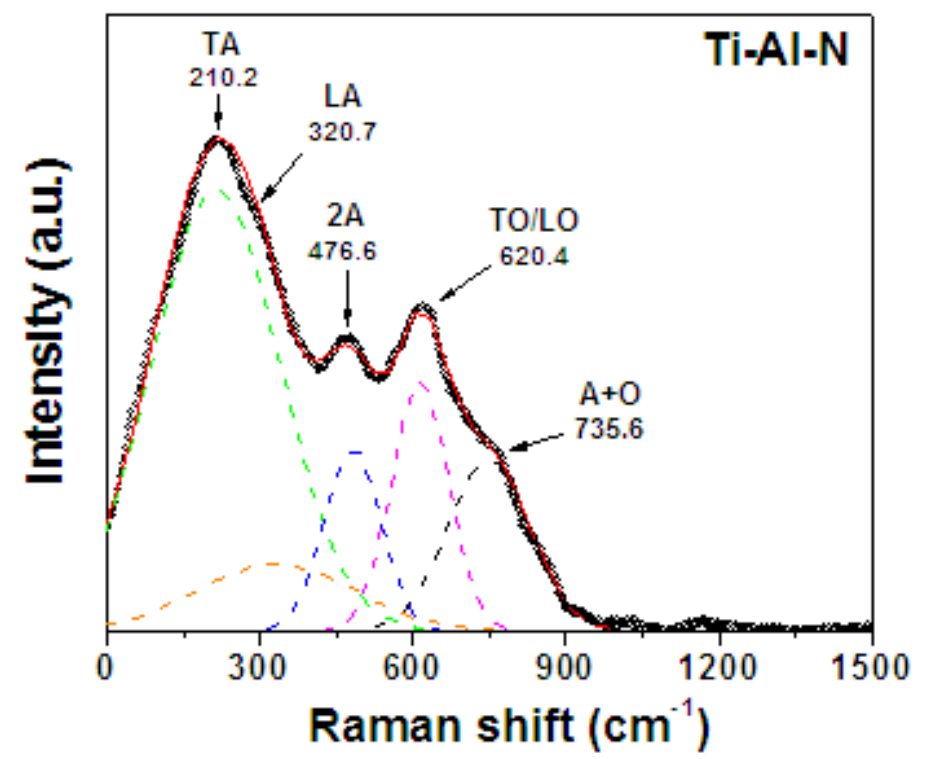

Fig. 9. Raman spectra of Ti-Al-N film.

\subsubsection{Cr-Al-N films}

Raman spectra of Cr-Al-N films can be fitted well with five Gaussian-Lorentzian peaks at approximately 236, 475, 650, 712 and $1410 \mathrm{~cm}^{-1}$. The Raman shifts of the main bands and assignments are given in figure 10 spectra of binary aluminum nitride films have been described elsewhere (Shum et al., 2004; Barata et al., 2001) and are not analyzed here.

The spectrum of Cr-Al-N films shows a intense band at $236 \mathrm{~cm}^{-1}$, this band originate due to acoustic transitions in the $150-300 \mathrm{~cm}^{-1}$ region (LA and TA) because of vibrations of Cr ions. Additionally was observed two weak bands at $475 \mathrm{~cm}^{-1}$ and $650 \mathrm{~cm}^{-1}$, this bands were associated to longitudinal and transversal optic vibrations (LO and TO) in the $400-650 \mathrm{~cm}^{-1}$ region. Bands at higher wave numbers arise via second-order transitions $(A+O, 2 O)$. With 
high probability, first-order optic and second-order acoustic modes (2A) strongly overlap in the wave number range between $400-1000 \mathrm{~cm}^{-1}$.

Typical features of Raman spectra of Al-Cr-N coatings are three broad bands separated by low intensity "gaps" (Fig. 10). In concordance by literature (Kaindl et al., 2006) the spectrum of the Al-Cr-N coating, the low wave number band is assigned to TA and LA modes, the mid-wave number band to $2 \mathrm{~A}, \mathrm{TO} / \mathrm{LO}$ and $\mathrm{A}+\mathrm{O}$ modes and the high-wave number band to $2 \mathrm{O}$ modes.

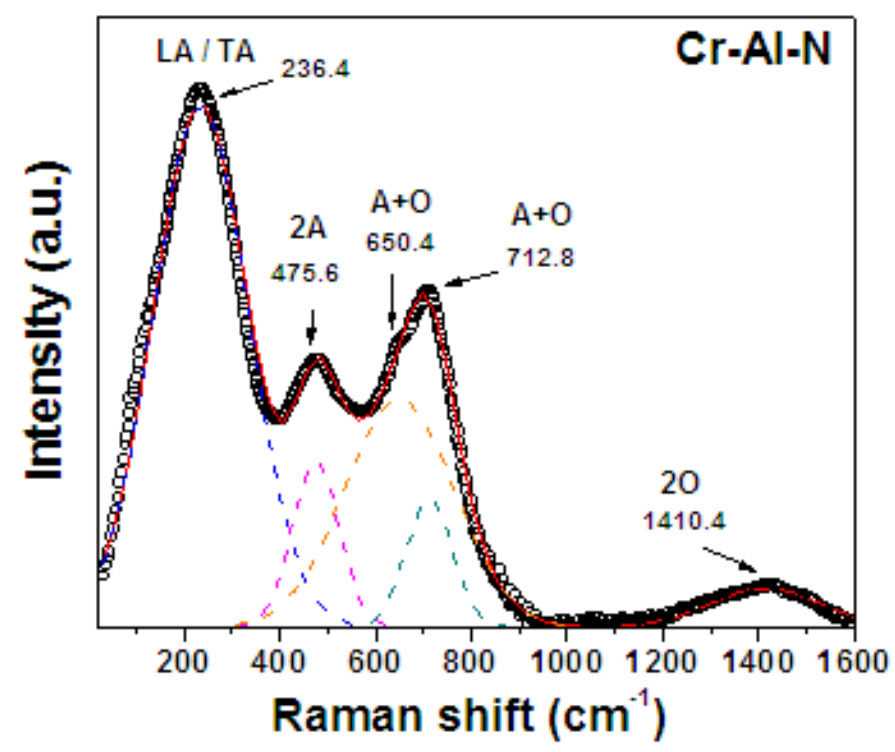

Fig. 10. Raman spectra of Cr-Al-N film.

\section{Conclusion}

The novel $[\mathrm{Ti}-\mathrm{Al} / \mathrm{Ti}-\mathrm{Al}-\mathrm{N}]_{\mathrm{n}}$ and $[\mathrm{Cr}-\mathrm{Al} / \mathrm{Cr}-\mathrm{Al}-\mathrm{N}]_{\mathrm{n}}$ nanometric multilayer structure was identified to be non-isostructural multilayer of Ti-Al, Cr-Al and Ti-Al-N, Cr-Al-N phases.

An exhaustive structural and compositional study was realized by X-ray photoelectron spectroscopy (XPS), Scanning electron microscopy (SEM), X-Ray Diffraction (XRD) and Raman spectroscopy. The preferential orientation for cubic TiAlN (200), AlN (002) and (301) tetragonal structure of TiAl single layer was shown via XRD. In $[\mathrm{Cr}-\mathrm{Al} / \mathrm{Cr}-\mathrm{Al}-\mathrm{N}]_{\mathrm{n}} \mathrm{XRD}$ pattern presents a cubic structure were the strongest peak corresponds to $\mathrm{CrN}$ (200) plane indicating a light textured growth along this orientation. From XPS results it was possible to identify the chemical composition in both single layer coatings. The SEM analysis confirmed well-defined multilayer structures and showed little variations in layer thickness ratio.

Raman spectra of Ti-Al-N and Cr-Al-N films show groups of bands in the acoustic and optical range, determined by Raman shifts and associated with typical phases present in these materials.

X-Ray spectroscopy techniques, such as, X-ray photoelectron spectroscopy (XPS), Scanning electron microscopy (SEM), X-Ray Diffraction (XRD) and Raman spectroscopy, are clearly 
powerful tools for the characterization of thin films and coatings with much scope for enhanced understanding of the structural and properties of future generations of PVD materials.

\section{Acknowledgment}

This research was supported by "El patrimonio Autónomo Fondo Nacional de Financiamiento para la Ciencia, la Tecnología y la Innovación Francisco José de Caldas" under contract RC-No. 275-2011 with Center of Excellence for Novel Materials (CENM). Moreover, the authors acknowledge the Serveis Científico-Técnics of the Centro de Investigación y de Estudios Avanzados del IPN, Unidad Querétaro, México and the Universitat de Barcelona for XPS and SEM analysis. L. Ipaz thanks Colciencias for the doctoral fellowship.

\section{References}

Allen G.C. \& Tucker P.M. (1976). Multiplet splitting of X-ray photoelectron lines of chromium complexes. The effect of covalency on the $2 p$ core level spin-orbit separation, Inorganica Chimica Acta, Vol. 16, pp. 41-45, ISSN 0020-1693.

Badrinarayanan, S.; Sinha, S. \& Mandale, A.B. (1989). XPS studies of nitrogen ion implanted zirconium and titanium. Journal of Electron Spectroscopy and Related Phenomena, Vol. 49, No. 3, pp. 303-309, ISSN 0368-2048.

Barata, A.; Cunha, L. \& Moura, C. (2001). Characterisation of chromium nitride films produced by PVD techniques, Thin Solid Films, Vol. 398-399, pp. 501-506, ISSN 00406090.

Barr, T.L. (1983). An XPS study of Si as it occurs in adsorbents, catalysts, and thin films, Applications of Surface Science, Vol. 15, No. 1-4, pp. 1-35, ISSN 0378-5963.

Barshilia, Harish C.; Deepthi, B.; Rajam, K.S. (2007). Deposition and characterization of $\mathrm{CrN} / \mathrm{Si}_{3} \mathrm{~N}_{4}$ and $\mathrm{CrAlN} / \mathrm{Si}_{3} \mathrm{~N}_{4}$ nanocomposite coatings prepared using reactive D.C. unbalanced magnetron sputtering, Surface \& Coatings Technology, Vol. 201, No. 24, pp. 9468-9475, ISSN 0257-8972.

Briggs, D. \& Seah, M. P. (1994). Practical Surface Analysis: Auger and X-ray photoelectron spectroscopy, 2 ed., Vol.1, pp. (641-644), John-Wiley \& Sons, ISBN 0-471-920, New York, USA.

Chen, Y.I. \& Duh, J.G. (1991). TiN coatings on mild steel substrates with electroless nickel as an interlayer. Surface \& Coatings Technology, Vol. 48, No. 2, pp. 163-168, ISSN 02578972.

Cheng, Y. H.; Tay, B. K.; Lau S. P. \& Shi X. (2001). Influence of substrate bias on the structure and properties of $(\mathrm{Ti}, \mathrm{Al}) \mathrm{N}$ films deposited by filtered cathodic vacuum arc. Journal of Vacuum Science \& Technology A, Vol. 19, No. 3, pp. 736-743, ISSN 0734-2101.

Constable, C.P.; Yarwood, J. \& Münz, W.-D. (1999). Raman microscopic studies of PVD hard coatings, Surface \& Coatings Technology, Vol. 116-119, pp. 155-159, ISSN 0257-8972.

Del Re, M.; Gouttebaron, R.; Dauchot, J.-P.; Leclère, P.; Terwagne, G. \& Hecq, M. (2003). Study of $\mathrm{ZrN}$ layers deposited by reactive magnetron sputtering, Surface $\mathcal{E}$ Coatings Technology, Vol. 174-175, pp. 240-245, ISSN 0257-8972. 
Endrino, J.L.; Fox-Rabinovich, G.S.; Reiter, A.; Veldhuis, S.V.; Escobar Galindo, R.; Albella, J.M. \& J.F. Marco. (2007). Oxidation tuning in AlCrN coatings, Surface \& Coatings Technology, Vol. 201, No. 8, pp. 4505-4511, ISSN 0257-8972.

Fox-Rabinovich, G.S.; Yamamoto, K.; Kovalev, A.I.; Veldhuis, S.C.; Ning, L.; Shuster, L.S. \& Elfizy, A. (2008). Wear behavior of adaptive nano-multilayered TiAlCrN/NbN coatings under dry high performance machining conditions. Surface $\mathcal{E}$ Coatings Technology, Vol. 202, No. 10, pp. 2015-2022, ISSN 0257-8972.

Geoffrey C. Allen, Michael T. Curtis, Alan J. Hooper \& Philip M. Tucker. (1973). X-Ray photoelectron spectroscopy of chromium-oxygen systems, Journal of the Chemical Society, Dalton Transactions, No. 16, pp. 1675-1683, ISSN 1477-9226.

Hironobu Miya, Manabu Izumi, Shinobu Konagata \& Takayuki Takahagi. (2003). Analysis of chemical structures of ultrathin oxynitride films by X-Ray Photoelectron Spectroscopy and Secondary Ion Mass Spectrometry, Japanese Journal of Applied Physics, Vol. 42, pp. 1119-1122, ISSN 0021-4922.

Ipaz, L.; Caicedo, J. C.; Alba de Sánchez, N.; Zambrano \& G.; Gómez, M. E. (2010). Tribological characterization of $\mathrm{Cr} / \mathrm{CrN}$ films deposited onto steel substrates by d.c. magnetrón co-sputtering method. LatinAmerican Journal of Metallurgy and Materials, Vol. 30, No. 1, pp. 82-88. ISSN 0255-6952.

Kaindl, R.; Franz, R.; Soldan, J.; Reiter, A.; Polcik, P.; Mitterer, C.; Sartory, B.; Tessadri, R. \& O'Sullivan, M. (2006). Structural investigations of aluminum-chromium-nitride hard coatings by Raman micro-spectroscopy, Thin Solid Films, Vol. 515, No. 4, pp. 2197-2202, ISSN 0040-6090.

Kim, Soo Young; Jang, Ho Won; Kim, Jong Kyu; Jeon, Chang Min; Park, Won Il; Yi, GyuChul \& Jong-Lam LeeSoo. (2002). Low-resistance Ti/Al ohmic contact on undoped ZnO. Journal of Electronic Materials, Vol. 31, No. 8, pp. 868-871, ISSN 0361-5235.

Kuo, Hong-Shi \& Tsai, Wen-Ta. (2000). Electrochemical Behavior of Aluminum during Chemical Mechanical Polishing in Phosphoric Acid Base Slurry, Journal of The Electrochemical Society, Vol. 147, No. 1, pp. 149-154, ISSN 0013-4651.

Lindsay, J.R.; Rose, H.J.; Swartz, W.E.; Watts, P.H. \& Rayburn, K.A. (1973). X-ray Photoelectron Spectra of Aluminum Oxides: Structural Effects on the "Chemical Shift", Applied Spectroscopy, Vol. 27, No. 1, pp. 1-5, ISSN 0003-7028.

Montgomery Jr., G.P.; Klein, M.V.; Ganguly, B.N. \& Wood, R.F. (1972). Raman scattering and far-infrared absorption induced by silver ions in sodium chloride, Physical Review B, Vol. 6, No. 10, pp. 4047-4060, ISSN 0163-1829.

Moreno, H.; Caicedo, J.C.; Amaya, C.; Cabrera, G.; Yate, L.; Aperador, W. \& P. Prieto. (2011). Improvement of the electrochemical behavior of steel surfaces using a $\mathrm{TiN}[\mathrm{BCN} / \mathrm{BN}]_{\mathrm{n}} / \mathrm{c}-\mathrm{BN}$ multilayer system. Diamond and Related Materials, Vol. 20, No. 4, pp. 588-595, ISSN 0925-9635.

Münz, W.D. (1986). Titanium aluminum nitride films: A new alternative to TiN coatings. Journal of Vacuum Science E Technology A, Vol. 4, No. 6, pp. 2717- 2726, ISSN 07342101.

Musil, J. \& Hruby, H. (2000). Superhard nanocomposite $\mathrm{Ti}_{1-x} \mathrm{Al}_{\mathrm{x}} \mathrm{N}$ films prepared by magnetron sputtering. Thin Solid Films, Vol. 365, No. 1, pp. 104-109, ISSN 0040-6090.

Nishimura O., Yabe K. \& Iwaki M. (1989). X-ray photoelectron spectroscopy studies of highdose nitrogen ion implanted-chromium: a possibility of a standard material for 
chemical state analysis. Journal of Electron Spectroscopy and Related Phenomena, Vol. 49, No. 3, pp. 335-342, ISSN 0368-2048.

PalDey, S. \& Deevi, S.C. (2003). Single layer and multilayer wear resistant coatings of (Ti,Al)N: a review. Materials Science and Engineering: A, Vol. 342, No. 1, pp. 58-79, ISSN 0921-5093.

Qu, X. X.; Zhang, Q. X.; Zou, Q. B.; Balasubramanian, N.; Yang, P. \& Zeng, K. Y. (2002). Characterization of TiAl alloy films for potential application in MEMS bimorph actuators. Materials Science in Semiconductor Processing, Vol. 5, No. 1, pp. 35-38, ISSN 1369-8001.

Sanchéz, J.E.; Sanchez, O.M.; Ipaz, L.; Aperador, W.; Caicedo, J.C.; Amaya, C.; HernandezLandaverde, M.A.; Espinoza-Beltrán, F.; Muñoz-Saldaña, J. \& Zambrano, G. (2010). Mechanical, tribological, and electrochemical behavior of $\mathrm{Cr}_{1-x} \mathrm{Al}_{\mathrm{x}} \mathrm{N}$ coatings deposited by r.f. reactive magnetron co-sputtering method. Applied Surface Science, Vol. 256, No. 8, pp. 2380-2387, ISSN 0169-4332.

Sanjinés, R.; Banakh, O.; Rojas, C.; Schmid, P.E. \& Lévy, F. (2002). Electronic properties of $\mathrm{Cr}_{1-\mathrm{x}} \mathrm{Al}_{\mathrm{x}} \mathrm{N}$ thin films deposited by reactive magnetron sputtering, Thin Solid Films, Vol. 420-421, pp. 312-317, ISSN 0040-6090.

Schönjahn, C.; Bamford, M.; Donohue, L.A.; Lewis, D.B.; Forder, S. \& Münz, W.-D. (2000). The interface between TiAlN hard coatings and steel substrates generated by high energetic $\mathrm{Cr}^{+}$bombardment. Surface \& Coatings Technology, Vol. 125, No. 1, pp. 6670, ISSN 0257-8972.

Setsuhara, Y.; Suzuki, T.; Makino, Y.; Miyake, S.; Sakata, T. \& Mori, H. (1997). Phase variation and properties of $(\mathrm{Ti}, \mathrm{Al}) \mathrm{N}$ films prepared by ion beam assisted deposition . Surface $\mathcal{E}$ Coatings Technology, Vol. 97, No. 1, pp. 254-258, ISSN 02578972.

Shieh, J. \& Hon, M.H. (2001). Nanostructure and hardness of titanium aluminum nitride prepared by plasma enhanced chemical vapor deposition. Thin Solid Films, Vol. 391, No. 1, pp. 101-108, ISSN 0040-6090.

Shulga, Y.M.; Troitskii, V.N.; Aivazov, M.I. \& Borodko. Y.G. (1976). X-ray Photoelectronspectra of scandium, titanium, vanadium and chromium mononitrides, Zhurnal Neorganicheskoi khimii, Vol. 21, No. 10, pp. 2621-2624, ISSN 0036-0236.

Shum, P.W.; Li, K.Y.; Zhou, Z.F. \& Shen, Y.G. (2004). Structural and mechanical properties of titanium-aluminium-nitride films deposited by reactive close-field unbalanced magnetron sputtering, Surface \& Coatings Technology, Vol. 185, No. 2-4, pp. 245-253, ISSN 0257-8972.

Shum, P.W.; Zhou, Z.F.; Li, K.Y. \& Shen, Y.G. (2003). XPS, AFM and nanoindentation studies of $\mathrm{Ti}_{1-x} \mathrm{Al}_{\mathrm{X}} \mathrm{N}$ films synthesized by reactive unbalanced magnetron sputtering. Materials Science and Engineering: B, Vol. 100, No. 2, pp. 204-213, ISSN 0921-5107.

Tam, P.L.; Zhou, Z.F.; Shum, P.W. \& Li, K.Y. (2008). Structural, mechanical, and tribological studies of Cr-Ti-Al-N coating with different chemical compositions. Thin Solid Films, Vol. 516, No. 16, pp. 5725-5731, ISSN 0040-6090.

Taylor, J.A. (1982). An XPS study of the oxidation of Al-As thin films grown by MBE. Journal of Vacuum Science \& Technology, Vol. 20, No. 3, pp. 751-757, ISSN 0022-5355.

Taylor J.A. \& Rabalais J.W. (1981). Reaction of $\mathrm{N}_{2}{ }^{+}$beams with aluminum surfaces, Journal of Chemical Physics, Vol. 75, No. 4, pp. 1735-1746, ISSN 0021-9606. 
Tien, S.-K. \& Duh, J.-G. (2006). Comparison of microstructure and phase transformation for nanolayered $\mathrm{CrN} / \mathrm{AlN}$ and TiN/AIN coatings at elevated temperatures in air environment. Thin Solid Films, Vol. 515, No. 3, pp. 1097-1101, ISSN 0040-6090.

Yashar, Philip C. \& Sproul, William D. (1999). Nanometer scale multilayered hard coatings. Vacuum, Vol. 55, No. 3, pp. 179-190, ISSN 0042-207X. 


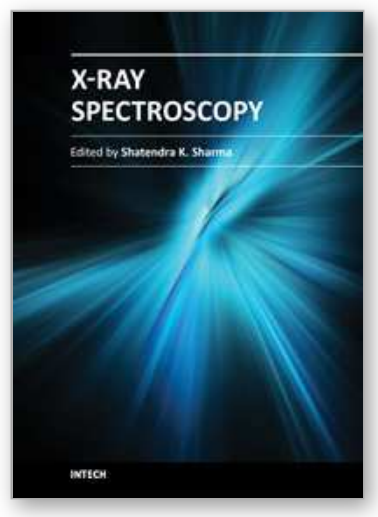

\author{
X-Ray Spectroscopy \\ Edited by Dr. Shatendra K Sharma
}

ISBN 978-953-307-967-7

Hard cover, 280 pages

Publisher InTech

Published online 01, February, 2012

Published in print edition February, 2012

The x-ray is the only invention that became a regular diagnostic tool in hospitals within a week of its first observation by Roentgen in 1895. Even today, $\mathrm{x}$-rays are a great characterization tool at the hands of scientists working in almost every field, such as medicine, physics, material science, space science, chemistry, archeology, and metallurgy. With vast existing applications of $x$-rays, it is even more surprising that every day people are finding new applications of $x$-rays or refining the existing techniques. This book consists of selected chapters on the recent applications of $x$-ray spectroscopy that are of great interest to the scientists and engineers working in the fields of material science, physics, chemistry, astrophysics, astrochemistry, instrumentation, and techniques of $x$-ray based characterization. The chapters have been grouped into two major sections based upon the techniques and applications. The book covers some basic principles of satellite $x$-rays as characterization tools for chemical properties and the physics of detectors and $\mathrm{x}$-ray spectrometer. The techniques like EDXRF, WDXRF, EPMA, satellites, micro-beam analysis, particle induced XRF, and matrix effects are discussed. The characterization of thin films and ceramic materials using $\mathrm{X}$-rays is also covered.

\title{
How to reference
}

In order to correctly reference this scholarly work, feel free to copy and paste the following:

Leonid Ipaz, William Aperador, Julio Caicedo, Joan Esteve and Gustavo Zambrano (2012). A Practical Application of X-Ray Spectroscopy in Ti-Al-N and Cr-Al-N Thin Films, X-Ray Spectroscopy, Dr. Shatendra K Sharma (Ed.), ISBN: 978-953-307-967-7, InTech, Available from: http://www.intechopen.com/books/x-rayspectroscopy/a-practical-application-of-x-ray-spectroscopy-in-ti-al-n-and-cr-al-n-thin-films

\section{INTECH}

open science | open minds

\section{InTech Europe}

University Campus STeP Ri

Slavka Krautzeka 83/A

51000 Rijeka, Croatia

Phone: +385 (51) 770447

Fax: +385 (51) 686166

www.intechopen.com

\section{InTech China}

Unit 405, Office Block, Hotel Equatorial Shanghai

No.65, Yan An Road (West), Shanghai, 200040, China 中国上海市延安西路65号上海国际贵都大饭店办公楼 405 单元

Phone: +86-21-62489820

Fax: +86-21-62489821 
(C) 2012 The Author(s). Licensee IntechOpen. This is an open access article distributed under the terms of the Creative Commons Attribution 3.0 License, which permits unrestricted use, distribution, and reproduction in any medium, provided the original work is properly cited. 